\title{
Discussion on Strengthening Humanistic Quality Education of Students in Military Academies
}

\author{
Yanming Yang \\ Qingdao Campus \\ Naval Aviation University \\ Qingdao 266041, China \\ yymqd@126.com
}

\author{
Yanmin $\mathrm{Li}$ \\ English Teaching and Research Section \\ Yucai Middle School Jinxiang County Shandong Province \\ Jinxiang 272200, China \\ jxxzyzzyh@163.com
}

\begin{abstract}
Humanistic quality is a man's intrinsic quality. Different humanities have different personality qualities. Enhancing humanistic quality is a necessary way to improve the comprehensive quality of the students, and is the objective requirement of military educational transformation. Based on the actual situation of military academies, this paper discusses the connotation of humanistic quality, the current situation of humanistic quality education in military academies and the necessity of strengthening humanistic quality education for military academy students. Finally the corresponding strategies are brought forward, which could facilitate the humanity quality education in military academies. It has important reference significance and value for the training of high quality military personnel with ability to fight and win the war.
\end{abstract}

Keywords-Humanistic quality; Military academies students; Quality-oriented education; Countermeasures

\section{INTRODUCTION}

One of the main educational challenges we still face today is the humanistic challenge, namely how to promote humanistic moral values, how to strengthen in students the motivation to be morally active, especially how to help them recognize the other as a human subject [1]. Humanistic quality means "the quality of a person integrated by various factors such as humanistic knowledge, abilities, concepts, emotions, and will, which is manifested through one's temperament, accomplishment, behavior and personality [2]." Humanistic quality is an important part of the comprehensive quality of military personnel and an important symbol of its overall development. Humanistic quality education refers to imparting the outstanding cultural achievements of mankind through knowledge, and enveloping the environment into personality, temperament and self-cultivation as the relatively stable internal character of man. For military academies students is to make it a firm ideals and beliefs, noble moral sentiment, profound humanistic background and a strong sense of mission and responsibility. The formation of these excellent qualities is inseparable from the humanistic education and training.

\section{CURRENT SituATION OF HUMANISTIC QUALITY EDUCATION IN MILITARY ACADEMIES}

The improvement of humanistic quality is the only way to improve the comprehensive quality of military academy students. Strengthening the construction of humanistic quality education system is the objective requirement of teaching transformation in military academies. At present, there are many problems in the humanistic quality education in military academies. Many military academies have not integrated the humanistic quality education activities into a three-dimensional, systematic and macroscopic education system, and the integration ability is not strong and the randomness is great. The quality education activities are not popular enough, and students' participation consciousness is not strong enough. In addition, students have more books knowledge, less social life knowledge, more business knowledge, less knowledge of people, logical thinking ability, but poor image thinking [3].

\section{A. Lack of humanities and cultural literacy}

Many students have little access to education about humanities and receive excellent Chinese traditional culture. Therefore, they have little knowledge of human cultural heritage and lack of understanding of the long history and culture of the Chinese nation. In particular, they lack the uniqueness of the Chinese nation influenced by the cultural, artistic and sentimental character, resulting in a decline in the overall cultural attainment [4].

\section{B. Emphasizing natural science and neglecting humanities and social sciences}

The military academies in our country have a tendency to emphasize natural sciences and light humanities and social sciences. Especially when education is influenced by the market economy and utilitarianism and does not put the improvement of people's quality in the right place, humanity education and science education are more likely to be segregated.

\section{Ignoring humanistic education leads to lower social adaptability}

From the current situation of the military academy, the humanistic education of the students has not attracted enough attention. On the one hand, we should pay attention to quality education; on the other hand, we still have too many marks of examination oriented education in the concept, teaching mode and educational management mode. Because many students all day immersed in the learning theory of science and technology 
knowledge, the lack of real relationships between people, people and collective relationship, the relationship between people and society, and scientific understanding of the relationship between man and nature, do not know how to should behave the relationship between truth, and social life environment exist adverse factors affect their mental health development, resulting in some students of non rational values, vulgar, eccentric personality, psychological ability and selfcontrol ability is low, they are easy to go to extremes, do not even know how to communicate with people.

\section{THE NECESSITY OF STRENGTHENING HUMANISTIC} QUALITY EDUCATION FOR MILITARY ACADEMY STUDENTS

High quality military personnel should have good ideological and political quality, military professional quality, scientific and cultural quality, excellent physical and mental quality. The quality of military personnel affects the fighting capacity and fighting spirit of the army. Strengthening the cultivation of humanistic quality of military academy students is helpful to cultivate high-quality military personnel who can fight and win the war, help to improve the cultural soft power of the army, and help to close the actual combat and achieve the goal of strengthening the army.

\section{A. Strengthening the humanistic quality education of military academy students is an urgent necessity for training qualities of talents during the new military reform}

The essence of modern war and ancient war has undergone profound changes. The confrontation of war has changed from a mechanized war to an informationized war. All countries in the world are actively developing advanced weapons and equipment in order to achieve the strategic goal they can win. But it should not be overlooked that no matter how advanced the weaponry is, it is human beings who decide to win the upper hand in the ever-changing, arduous and complex battlefield. People are alive and weapons and equipment are dead To make the most advanced combat effectiveness of advanced weapons and equipment depend on the high level of professionalism and bravery and tenacious fighting spirit, Quality of high-quality military personnel. This accomplishment is not the result of cultivation of science and technology but the result of cultivation of humanistic qualities. Therefore, the military academies and universities should vigorously step up the education of humanistic quality to provide powerful personnel support for the new military revolution.

\section{B. Strengthening the humanistic quality education of military academy students is an urgent need to promote the modernization of the armed forces}

Yang Shuzi, a member of the Chinese Academy of Sciences, commented on Humanism:" humanistic culture is the identity card of a nation. Without advanced science and technology, we will be defeated by a dozen; without the spirit of humanity and national tradition, a country and a nation will not break down." Academician Yang's words not only pointed out the important position of science, but also emphasized the basic function of humanities.
In the current era, the new world military revolution is in the ascendant, and high and new technologies are being taken more and more in the military field. All countries have invested a lot of manpower, material and financial resources in order to win the initiative in the modernization of the armed forces. The modernization of the army is, in the final analysis, the modernization of man. The modernization of the military personnel is not only the mastery of professional knowledge and skills, but also the cultivation of liberal knowledge and the development of freedom and all-round development. Therefore, as a military academy, we should not only strengthen the teaching and research of military theory and military skills, but also constantly increase the cultivation of human knowledge, and strive to cultivate more military talents who are not only excellent in technology, but also rich in humanistic knowledge and humanistic quality.

\section{Strengthening humanistic quality education for military academy students is the general trend of military education in the world}

To strengthen the humanistic quality education of military academy students is the requirement of the development of the times and the trend of the world military higher education reform. West Point, the oldest Military Academy in the United States, is so positioned itself. "Today, West Point first is a college of humanities, which takes the knowledge of change as the center", and accordingly identifies the design teaching, and introduces various measures for the cultivation of humanistic quality and strictly implements it.

In recent years, the Russian attention to humanistic education has also increased year by year, and constantly strengthen the military humanistic quality education, and regard it as the basis and power of combat effectiveness. At present, our army also recognizes the importance of humanistic quality education, and attaches importance to the humanistic quality education, so as to conform to the trend of the world military higher education reform.

\section{THE COUNTERMEASURES FOR MILITARY ACADEMY STUDENTS TO STRENGTHEN HUMANISTIC QUALITY EDUCATION}

Humanistic quality education is not only related to classroom education, but also related to daily training, and closely related to training, management and life. Therefore, humanistic quality education should be designed and promoted as a comprehensive system project.

\section{A. Set up the modern educational idea of mutual integration of science education and humanistic education}

The concept of modern education consists of four pillars of theory: learning to know, learning to do, learning to live together and learning to be. While emphasizing science education, it emphasizes humane education and humane spirit in science education so as to make both complement each other in educational content and integrate in education ideology and promote each other. This philosophy emphasizes guiding and satisfying both human needs and promoting the harmonious development of ego, self and others, self and nature, self and 
society. The fundamental starting point is the all-round harmonious development of human beings. The ultimate goal is human happiness.

The essence of modern education lies not only in imparting knowledge and skills, but also in shaping personality and improving human nature. Military academy education should prevent and overcome the tendency of emphasizing science and humanistic culture, and earnestly cultivate a large number of all-round high-level talents needed for national defense and army modernization.

\section{B. Adjusting the humanities curriculum system}

In China's military academies, due to the traditional utilitarian concept of education, most of the science and engineering based, humanities courses accounted for a small proportion, often as a professional course outside the expansion of student interest in the auxiliary course, long-term attention. In order to change this situation and improve students' humanistic quality, it is necessary to adjust the curriculum system of military academy and form a complete and systematic humanistic curriculum system [5].

First of all, gradually add different types of humanities courses, and constantly expand the scope and content of the humanities curriculum, build a complete and systematic humanities curriculum system. Secondly, we should gradually improve the proportion of humanities courses, and appropriately increase the required courses and elective courses of humanities and social sciences.

At present many courses at military colleges and schools of humanities disciplines and totally pathetic this situation directly affects the humanities courses teaching quality and teaching effect of most of the teaching content can only be tasted some have enough time to guide students to further reflection and discussion. Therefore, in order to improve students' humanistic quality and cultivate their humanistic spirit, we must appropriately increase the required courses and elective courses of humanities and social sciences.

\section{Improve the comprehensive quality of teachers, cultivate the humanistic feelings of teachers}

The Book of Rites states: "The teacher, who teaches things to do with virtue," also said: "Good singers make people follow their voices; good teachers make people follow their own ambitions." This means that teachers not only teach but also educate people, not only to impart scientific knowledge but also to cultivate humanism. Sukhomlinski, a famous former Soviet Union educator, once said that "teachers are not only teachers of their own disciplines, but also educators of the students, mentors of life and moral guides [6]." To improve the humanistic quality of military academy students, the key depends on the qualifications of the teaching staff, which requires military academy teachers not only have a solid professional knowledge, a high level of teaching ability, but also have extensive knowledge of the humanities and a higher humanity.

However, at present in military academies and universities, especially in engineering and technical colleges, trainees tend to think that cultivating the humanistic quality of trainees is a matter for teachers of politics and social sciences, paying attention to the imparting of knowledge in the subject and neglecting cultivation of humanistic spirit of trainees. In fact, humanities are full of natural sciences and engineering disciplines. Teachers should be a good moral character, a high degree of professionalism, selfless dedication noble personality charm subtly guide students focus on the value of human life and significance of life; to guide students to form a positive, healthy and perfect personality, so that students a comprehensive coordinated development [7].

\section{Promoting the humanistic quality of students with chinese classics}

After thousands of years of accumulation, Chinese classics concentrated the profound philosophy and the wisdom of the sages, and conducted the classical Chinese education in the military academies, which is good for enhancing the humanistic accomplishment of the students. The Doctrine of the Mean states that "learn extensively, inquire thoroughly, ponder prudently, discriminate clearly and practice devotedly." This process of learning from thinking, thinking and thinking about what is going on is actually a process of enhancing humanistic quality. Military academy students learn classical Chinese classics, which can better disseminate the national spirit of the Chinese nation.

In the course of history, the Chinese nation has created a series of excellent national spirits, which are closely related to the classics of Chinese culture. Such as: "As Heaven's movement is ever vigorous, so must a gentleman ceaselessly strive along; as the environment is disadvantageous, but the gentleman hold world with virtue." The historical connotation of "Strengthen self without stopping" manifests itself in the political life, individual life and working attitude, while "Hold world with virtue" shows itself in the national relationship, cultural value, human relationship and state management.

From Wen Tianxiang's " Everyone must die; let me but leave a loyal heart shining in the pages of history." to $\mathrm{Gu}$ Yanwu's "Everyone is responsible for his country.", which reflects the strong spirit of patriotism. In addition, the benevolent love humanity, honesty and social virtues, innovative consciousness and lofty ideals and so on, these are the spirit of the Chinese nation and the classical philosophers Ancient Chinese Literature Search strongly. It can be said that without Chinese classics, there will be no such excellent national spirit of the Chinese nation. These national spirits, in today's ideological and political education of students, has very important educational value.

\section{E. Constructing humanistic environment and creating humanistic atmosphere}

Human environment is the heritage of a college. The level of humanities education reflects the taste and style of a university and affects the prospects of further development of the school. Deep historical and traditional, colorful campus culture, elegant campus environment, rich cultural landscape, for students to broaden their horizons, active thinking, sublimation of personality, the spirit of molding play an 
irreplaceable role. We must step up the building of a campus culture and create a good atmosphere for humanistic education so as to achieve both a macro and a magnificent training ground and a wide range of cultural corners. There are various competitive competitions that will forge the willpower of the soldiers and cultural activities that mold the soldiers [8].

We should establish a campus culture framework featuring students as the main target, campus as the main space, and the spirit of the times as the main theme. We will hold a series of lectures that will help improve the humanistic accomplishments of military academy students, carry out humane reading activities and organize students to develop healthy, lively and rich colorful campus cultural activities and actively guide students to care more and think about life and society and other issues, enhance their sense of historic mission and social responsibility, enable students to enlighten and enrich their emotions in a variety of cultural activities, and at the same time For students the future development, a better life, work, learning to provide a broad cultural heritage.

\section{CONCLUSIONS}

Nowadays, it is necessary to attach importance to humanistic quality education in order to train high-quality military personnel who can fight and win battles. In order to achieve the goal of strengthening the army and improve the combat effectiveness of the army, we should pay more attention to the humanistic quality education. Therefore, strengthening the humanistic quality education and training of military academy students has important reference significance and reference value for deepening the reform of military colleges and universities, promoting quality education and training high-quality military personnel.

\section{REFERENCES}

[1] Schwarzfranco, Orit. "Touching the challenge: Embodied solutions enabling humanistic moral education." Journal of Moral Education (2016):1-16.

[2] Xianzhang HU, Baogeng XU and Dening YUAN. "Some Thoughts on Strengthening Humanistic Quality Education." China Higher Education (1996): 29-30. (In Chinese)

[3] Xuan, LIU, Chengguo QIAO. " Enhancing cadets' humanistic quality in military academies." Journal of Naval University of Engineering, 7.4 (2011): 34-36. (In Chinese)

[4] Su, Jing. "The Value of Poetic Teaching in the Cultivation of Normal Students' Humanistic Quality." Review of Higher Education (2016).

[5] Dan LI, Xiaoli XU and Yanping SONG. " An Analysis of Humanities Quality Cultivation Mode in Military Academies." Journal of Lanzhou Institute of Education, 30.7 (2014): 111-112. (In Chinese)

[6] Sukhomlinski, Suggestions Which Give to Teacher, Educational Science Press, 2016.

[7] Sheng-Qiu, X. U., Q. G. Liu, and W. Zhang. "Discussions on Teachers Humanistic Quality of Military Academy." Journal of Air Force Radar Academy, 25.2 (2010): 149-151.

[8] Liu, Qing Guo, L. I. Sha-Lan, and B. H. Yan. "Analysis of the Actuality of Humanity Quality Education in Military Academies and Its Stratigies." Journal of Air Force Radar Academy, 22.3 (2008): 232-234. 